Later.

"Fourteen butterflies emerged from the chrysalids, but some of them did not disclose the imago, but dried up in the box, retaining their natural appearance. I send these in a roll of paper."
Explanation of Plate 4.

Fig. I. Spalgis s-signata Holland. Chrysalis enlarged.

Fig. 2. Same. Chrysalis, nat. size.

Fig. 3. Same. Larva.

Fig. 4. Same. Imago.

\title{
LIFE HISTORY OF ORGYIA CANA HY. EDW.
}

BY IIARRISON G. DYAR.

\section{Orgyia cana Hy. Edw .}

I881.-H. Edwards, Papilio, v. I, p. 62.

Egg. Slightly conoidal though almost spherical, smooth, shiny, opaque white, with a faint brownish spot and ring at the flattened end; diameter $\mathrm{I} \mathrm{mm}$. The eggs are laid in a mass on the cocoon of the female moth, fastened together by a slight amount of froth and thickly covered with the faintly brownish down from the body of the moth. The winter is passed in this stage, the little larvae hatching in the spring and emerging as mature moths in July and August. There is but one brood a year.

First larval slage. Head shining black, labrum a little paler; width o $4 \mathrm{~mm}$. Body sordid purplish black, a dorsal yellowish shade on joints 3,4 and 9 and a whitish stigmatal line. Warts black, the subdorsal ones on joint 2, large; hair thin, but several hairs grow from each wart, black. There are no brush-like tufts, hair pencils nor retractile tubercles, but the places of the latter are indicated by a dorsal red spot on joints ro and I r respectively, not elevated.

Second stage. Head brownish black, shiny; width $0.7 \mathrm{~mm}$. Body and warts black, hair thin, bristly and black. The subdorsal warts on joint 2 are large, but there are no brush tufts nor pencils. The retractile tubercles are present on joints Io and II, small, and colored dull blood red. The dorsum is paler on joints 3,4 and 9 .
Third stage. Head black with a brownish tinge, labrum white; width I.I-I.3 mm. Body black except on the dorsum of joints 3 and 4 where it is yellowish white with a black dorsal line, and also a yellowish subdorsal spot on joints 9 and ro (anteriorly). Warts all black; hair long, black with pencils of short, plumed, black hairs from the subdorsal warts of joint 2 (none on joint 12 ). There are small, dorsal, black, brush-like tufts on joints 5 and 6 and a few short tufted white hairs on joints 7 and 8 . The warts of row 2 on joint 9 are a little tinged with red. Retractile tubercles red. Length of larva about $9 \mathrm{~mm}$.

Fourth stage. Head brownish black, labrum and antennae sordid white; width r.7I. $8 \mathrm{~mm}$. Body greenish black below, gray on the sides, a black subdorsal and yellow subventral line. Dorsum largely sordid yellow; cervical shield, a dorsal line on joints 3 and 4 , a shade surrounding the tufts on joints $5-8$, and a broad band from joint 9 posteriorly to joint I2, all black; joint 13 dark gray. The warts of rows $x-5$ and the retractile tubercles are all blood red, concolorous, except those on joint 2 which are black. The plumed pencils on joint 2 are $2.5 \mathrm{~mm}$. long, and there is now also one on joint 12 dorsally. The brush-like tufts on joints 5 and 6 are brown, those on 7 and 8 white. The other hair is long and black but whitish subventrally. 
Fifth stage. Head shining black with a faint brownish tinge, labrum and antennae pale yellow; width $2.1-2.6 \mathrm{~mm}$. The body is colored as in the previous stage but the black shade surrounding the brush tufts fills in nearly all the dorsal space; hair pencils from joints 2 and $12,3 \mathrm{~mm}$. long. Spiracles black, a white dot posterior to each. The arrangement of the warts is as follows: row I anteriorly next to dorsal line on joints 5I2; 2 subdorsal; 3 suprastigmatal ; [4 absent, represented by the white dots posterior to the spiracles;] 5 subventral; 6 also subventral, just above the bases of the legs and a little posterior to the other warts; and row 7 consists of four small warts on the venter of the legless segments. On joint 2 warts 2 and 3 are on the cervical shield. small; 4 is large, subdorsal; 5 also large, lateral. On joints 3 and 4 all are present but $I$ and moved up somewhat. On joint 13 there are but three warts, the upper two large besides very minute ones on the anal plate. The brush tufts arise from wart I and the upper part of 2.

Sixth stage (all $\delta$ and some $q$ mature larvae). Head brown-black, shiny, clypeus pale centrally, labrum and antennae white; width, 3.1-3 $6 \mathrm{~mm}$. Body velvety black, a broken buff subdorsal line on joints 3 and 4 , represented by buff or yellow spots on joints 5 and 8-I I a little farther down the sides; a similar smaller subventral row running the whole length. Cervical shield pale, shaded with black, its warts crimson. The warts of rows I-5 are fine dark crimson, large, the hair long and black. Plumed pencils black, $7.5 \mathrm{~mm}$. long, showing a marked difference from the previous stage. Retractile tubercles crimson, a little brighter than the warts. Brush tufts large, all unicolorous, brownish silver gray, darker along the crest, showing another marked difference. Feet reddish, black at their bases. As the stage advances the brush tufts become black centrally, the side hairs remaining white.

Serenth stage (some + larvae only). Head round, brownish black, shiny, a pinkish white line above the mouth; antennae reddish, ocherous at base; width $4 \mathrm{~mm}$. Body dark gray, black dorsally, a broken subdorsal band nearly covering the dorsum on joints 3 and 4 and a broken substigmatal band. All the warts of rows I, 2, 3 and 5, retractile tubercles and cervical shield fine crimson, the tubercles a little brighter. The warts of row 4 are present but very small, situated back of the spiracles and colored ocher yellow.

Cocoon. Oval, regular, nearly opaque, composed of hair and silk.

$\delta$ pupa. Robust; wing and antenna-cases prominent; abdomen tapering, cremaster long, terminating in minute hooks; sparsely covered with rather short fine whitish hairs. Color rather light brown; spiracles black. Length $12 \mathrm{~mm}$.; width $5 \mathrm{~mm}$.

o pupa. Very large and robust, thorax and cases small, wing-cases of moderate size; abdomen nearly cylindrical, cremaster flattened, ending in many hooks. Smooth very shiny pale brown, with a few sparsely distributed pale hairs; spiracles black. Length $22 \mathrm{~mm}$. ; width of abdomen $9 \mathrm{~mm}$., of thorax $4.5 \mathrm{~mm}$.

Food plants. Species of oak (2)uercus kelloggii and 2. chrysolepis) also wild coffee (Rhamnus californica) and willow (Salix).

Larvae from Yosemite, Cal.

of moth. Primaries dark gray, whitish scales thickly scattered on a nearly black ground; an obscure black basal line and a brownish patch outside this, covering the lower half of the wing before the t. a. line, edged above by a black line and narrowly separated from the $t$. a. line. Transverse anterior line broad, black, gently waved and slightly produced outwardly above $\mathrm{m}$. vein; a reniform discal spot, outlined in black, filled in with a yellowish white shade and narrowly bordered with whitish. Transverse posterior line starting from costa almost above reniform, passing outward and around the spot and continuing to internal margin parallel 
to t. a. line. On the costa beyond t. p. line a black patch from which proceeds the whitish subterminal line, almost parallel to the t. p. line and most strongly marked just before its junction with internal margin, almost forming a white crescent. A black terminal line. Fringes blackish, interrupted with paler.

Secondaries blackish with a chestnut tint, especially centrally. Below nearly uniform dark blackish gray with a slight chestnut tint; discal dot and t. p. line indicated in black. o moth. Abdomen extremely large, thorax small, legs slender, wings larger than usual, $6 \mathrm{~mm}$. long. Color white with a faint brownish tinge; down dense, especially on the under side of abdomen ; dorsum broadly dark cinereous, both on thorax and abdomen; wings faintly brownish; eyes black. Antennae shortly pectinated. Length $18 \mathrm{~mm}$; width of abdomen $12 \mathrm{~mm}$.

Habitat probably the Sierra Nevada of California. Recorded from Havilah, Kern Co., (Hy. Edw.) and Yosemite, Mariposa Co.

\section{A LIST OF SOME OF THE CATALOGUES AND LOCAL LISTS OF NORTH AMERICAN COLEOPTERA.-III (R.-Z.).}

\section{BY JOHN HAMILTON AND SAMUEL HENSHAW.}

I05 Rauterberg, Fr. Coleoptera of Wisconsin. (Proc. nat. hist. soc. Wis., 1885, p. I0-25.)

A list of 260 species and varieties of Cicindelidae and Carabidae with notes on the locality and time of occurrence.

Io6 Reed, E. B. Coleoptera taken in the neighborhood of London, Ont. (Can. ent., r869, v. r, p. 69-70.)

Number of families (31) genera (129) and species ( 180 ) found in the vicinity of London, Ont.; over 130 undetermined species additional to the above have been collected.

Io7 Reinecke, Ottomar. Additional list of Coleoptera. (Bull. Buff. soc. nat. sci., I 882 , v. 4, p. 55.$)$

N. Y. 44 .

Reinecke, Ottomar. See : ZESc'H, Frank H.

Io8 Ritchie, A. S. On the Coleoptera of the Island of Montreal. (Can. nat. and geol., 1869, ser. 2, v. 4, p. 27-36.) Separate: I I p.

215 species are listed from the Island of Montreal and 3I Canadian species taken outside the Island of Montreal.

Io9 Sahlberg, John. Coleoptera och medlemmar a Berings Sunds Amerikanska Hemiptera insamlade af Vega-expeditionens kust. (Vega-exped. vetens. iaktt., I $88_{5}$, bd. 4 , p. 59-7 I.)

16 species of Coleoptera are listed from Port Clarence, Grantley Harbor and Bay of Iman-Ruk. r io Saunders, W. Entomological notes during a trip to Saguenay. (Can. ent., I 868 , v. I, p. I I-I 3.)

18 species are listed with localities.

Savage, H. See : HaywArd, R.

I I Say, Thomas. Descriptions of coleopterous insects collected in the late expedition to the Rocky Mountains, performed by order of Mr. Calhoun, Secretary of War, under the command of Major Long. (Journ. acad. nat. sci. Phil., I823, v. 3 , p. I39-216; I 824 , p. $238-282 ; 298-331 ; 403-462 ;$ I 824 , v. 4 , p. 83-99.) Ed. Leconte, v. 2, p. 89-236.

Describes 354 species.

I 2 Schaupp, F. G. The Cicindelidae of the neighborhood of $\mathrm{New}$ York. (Bull. Brooklyn ent. soc., 1878 , v. I, p. 28.)

A list of 15 species with localities and times of appearance.

I 3 Schaupp, F. G. [Florida Coleoptera.] (Bull. Brooklyn ent. soc., I878, v. I, p. 34.)

Adds I 3 species to those listed by Schwarz.

II4 Schaupp, F. G. List of Carabidae found in the neighborhood of New York city. (Bull. Brooklyn ent. soc., $188_{3}$, v. 6 , p. 29-32; 7 I-72.)

212 species are listed with localities and times of appearance. 

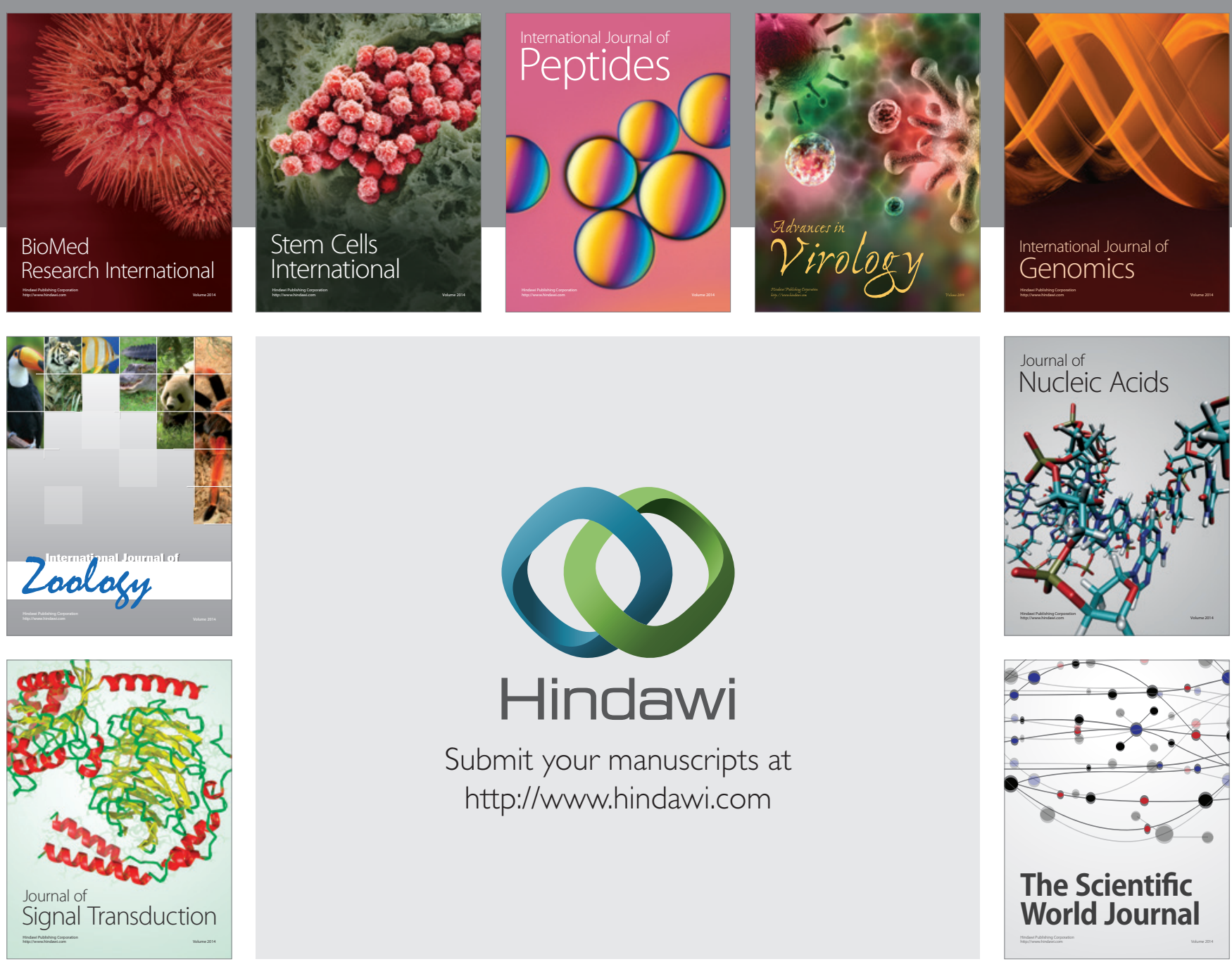

Submit your manuscripts at

http://www.hindawi.com
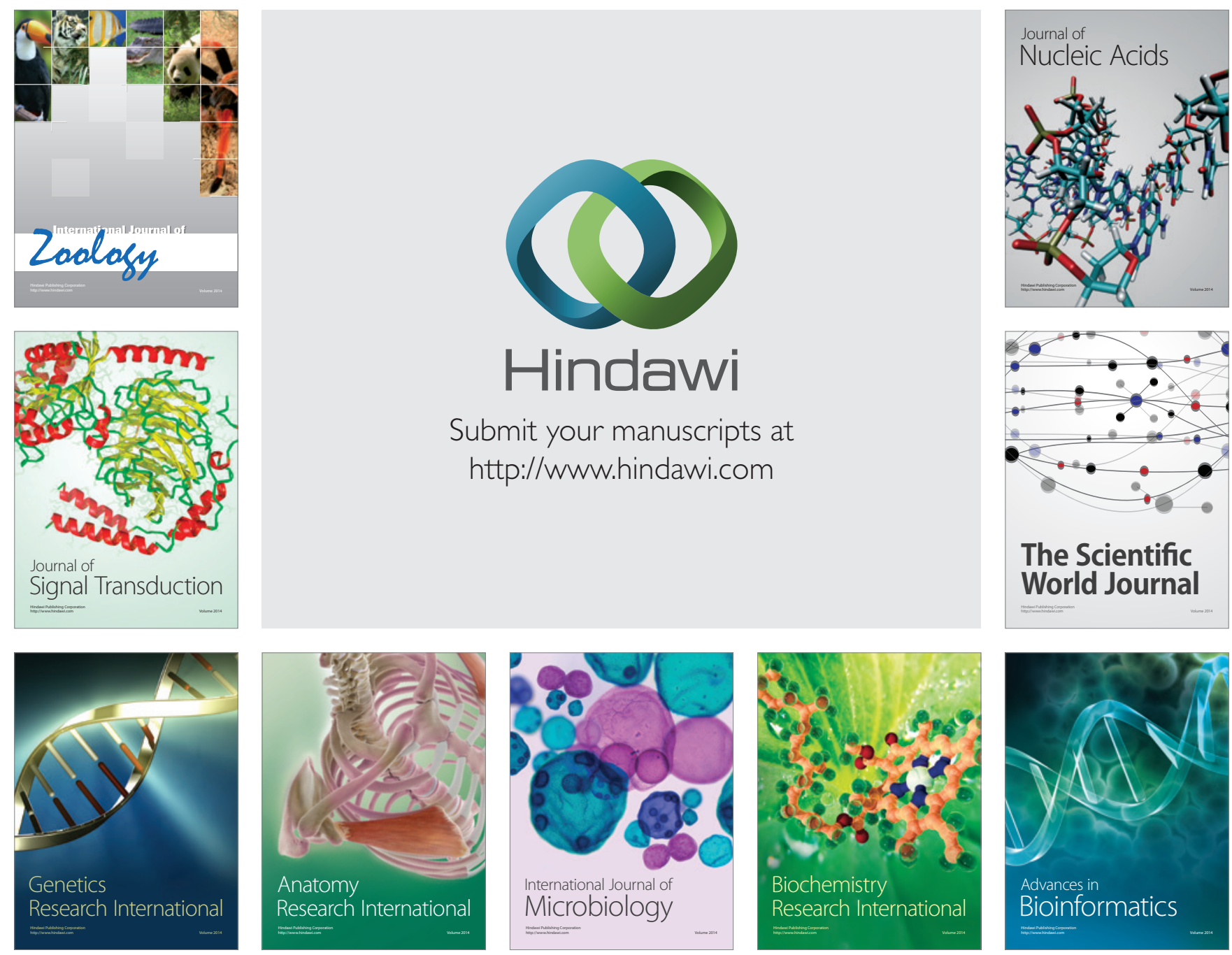

The Scientific World Journal
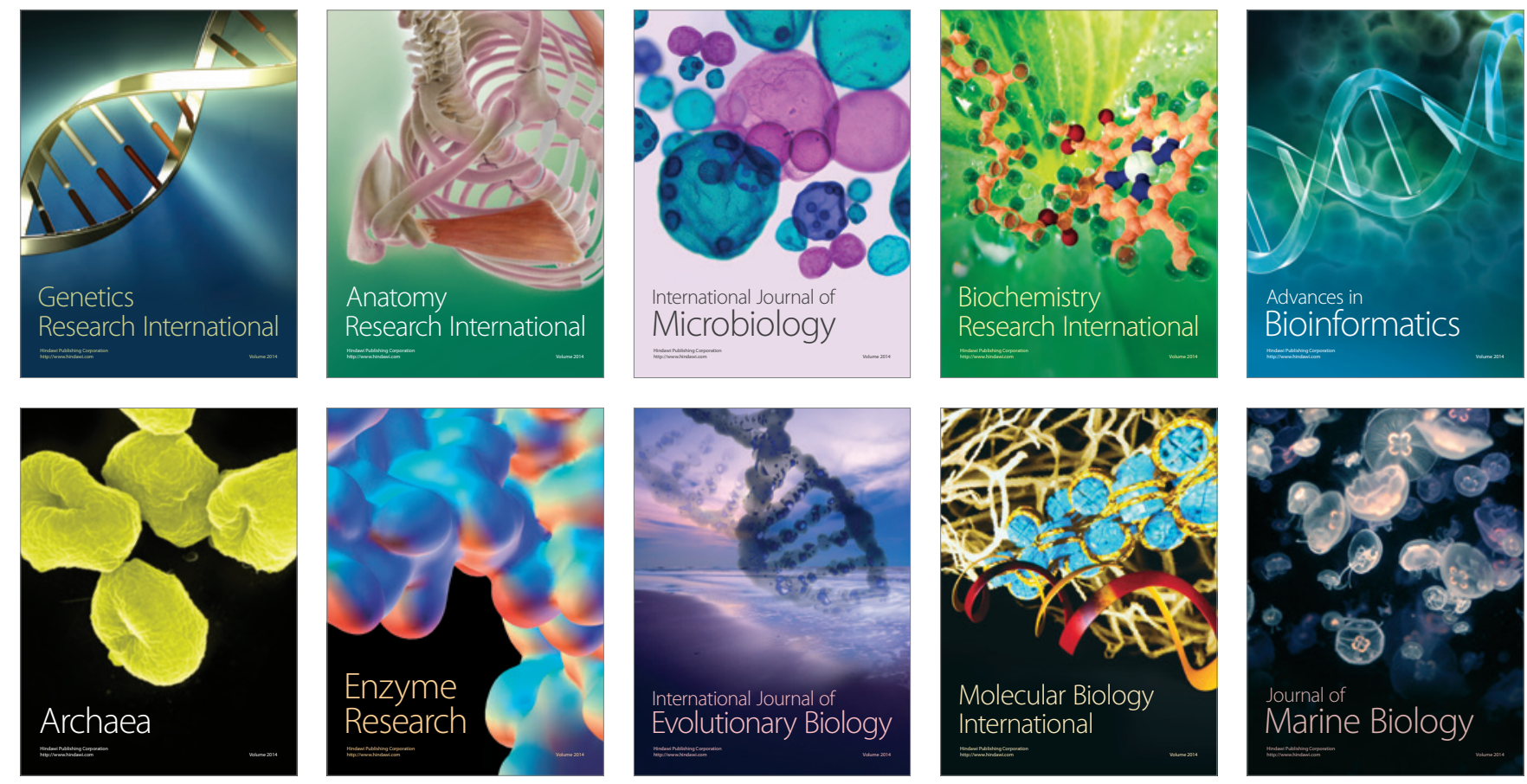